\title{
小児マイコプラズマ感染症の治療期間に影響を与える要因の探索
}

\author{
高岡雄一 ${ }^{* 1}$, 本田勝亮 ${ }^{1}$, 鈴木理恵 ${ }^{1}, 川$ 村和美 ${ }^{1,2}$, 松林 正 $^{3}$, 塩川 満 ${ }^{1}$ \\ 総合病院聖隷浜松病院薬剤部 ${ }^{1}$, シップヘルスケアファーマシー東日本 $(\text { 株 })^{2}$ \\ 総合病院聖隷浜松病院小览科 ${ }^{3}$

\section{Investigation of the Factors Affecting the Treatment Period of Child Mycoplasma Infection}

\author{
Yuichi Takaoka*1, Katsuaki Honda', Rie Suzuki', Kazumi Kawamura”, ${ }^{1,2}$ \\ Tadashi Matsubayashi ${ }^{3}$ and Mitsuru Shiokawa ${ }^{1}$ \\ Department of Pharmacy, Seirei Hamamatsu General Hospital ${ }^{1}$, \\ Ship Healthcare Pharmacy East Japan Co, Ltd ${ }^{2}$, \\ Department of Pediatrics, Seirei Hamamatsu General Hospital ${ }^{3}$ \\ $\left[\begin{array}{l}\text { Received July 22, } 2014 \\ \text { Accepted October 31, 2014 }\end{array}\right]$
}

Mycoplasma pneumonia is caused by infection of Mycoplasma pneumoniae, and is a frequently occurring infectious disease transmitted from children to young adults. Macrolides are recommended as first-line drugs, minocycline (MINO) and tosufloxacin (TFLX) are used for the second-line drugs. In this study, we investigated the factors affecting the treatment period of mycoplasma pneumonia.

We compared the effects of azithromycin (AZM), TFLX and MINO. The duration from hospitalization to defervescence was shorter in the MINO group than in the TFLX group. We then attempted to identify the factors that affect the treatment period of mycoplasma pneumonia. Patients who were treated in accordance with the Guidelines for the Management of Respiratory Infectious Diseases in Children in Japan 2011 (Guideline) showed shorter duration of fever and disease duration as compared with patients who were not treated in accordance with the guidelines.

In the case macrolides are ineffective, quickly switching to other drugs showed higher efficiency. In the light of these results, as treatment is carried out in accordance with the Guidelines, the disease and fever periods are shortened, and prolonged treatment in children could be prevented. These results also suggest that MINO is more effective for the treatment of mycoplasma pneumonia than TFLX.

Key words — Mycoplasma pneumonia, Mycoplasma pneumoniae, guideline, AZM, TFLX, MINO

\section{緒言}

マイコプラズマ肺炎は, Mycoplasma pneumoniae を原因とし発熱・咳・倦意感・頭痛などを主症状 とする呼吸器感染症である。通常 1 ～週間の潜 伏期間の後, 発熱に続いて咳が出現し, 解熱回復 した後も咳が 3〜4 週間続く場合がある. 全ての 年齢層で感染のリスクがあるが感染症発生動向調
査によると, 日本での罹患年齢は幼児期, 学童期, 青年期が中心と報告されている. ${ }^{1)}$ 特に小学生か ら若年成人の肺炎は，本菌が原因であることが多 く, 小児科では発生頻度の高い感染症の 1 つと言 える.

マイコプラズマ肺炎の治療には, 非定型細菌に 有効とされる抗菌薬が投与される. マクロライド 感受性株に対するマクロライド系薬の最小発育阻

\footnotetext{
* $\overline{\mathrm{T}} 430-8558$ 静岡県浜松市中区住吉2-12-12
} 
止濃度（minimum inhibitory concentration: MIC）は 極めて低く, ${ }^{2-4)}$ 治療終了時には気道から除菌され る. ${ }^{5,6)}$ 一方, Mycoplasma pneumoniae に対するキノ ロン系薬およびテトラサイクリン系薬の MIC は比 較的高く, 治療終了時には一部の症例で気道に菌 が残り感染を広げる可能性がある。 ${ }^{77}$ 従って，小览 呼吸器感染症診療ガイドライン $2011^{8)}$ (ガイドライ ン）には，マクロライド感受性株によるマイコプ ラズマ肺炎であればマクロライド系薬が第一選 択，マクロライド耐性株に対して効果が期待でき る小児適応のある抗菌薬は, minocycline (MINO) および tosufloxacin（TFLX）と明示されている. テトラサイクリン系薬は, 一過性骨発育不全, エ ナメル質形成不全などの有害事象を有するため, 8 歳未満には原則禁忌であり, ${ }^{9}$ 肺炎例で使用の必 要がある場合には TFLXが選択される。しかし， マイコプラズマ感染症はTFLXの適応症に含まれ ないため, キノロン系薬の使用に当たっては慎重 かつ限定的に使用されなくてはならない.

本邦では, 近年マクロライド耐性マイコプラズ マが増加してきている. ${ }^{10)}$ しかし， マイコプラズ マに対するマクロライド感受性の評価は遺伝子変 異を確認する必要があり, 臨床現場における全例 の実施は現実的に困難である。マクロライド系薬 の投与でマクロライド感受性株によるマイコプラ ズマ肺炎は，投与 48 時間後には大半が解熱する と考えられている. ガイドライン上, 推奨される マクロライド系薬投与 48 時間後に解熱が得られ ない場合, TFLX あるいは MINOへの変更は現実 的かつ有用な治療指針になると考えられる.今回, 静岡県西部地区においてマイコプラズマ肺炎の好 発時期であった患児を対象に調査を行い，抗菌薬 選択を含め治療期間に影響を及ぼす因子について 検討したので報告する.

\section{方法}

\section{1. 対象患者}

当院小児科病棟において 2012 年 3 月 1 日〜 2012 年 8 月 31 日の期間に, マイコプラズマ肺炎 で入院し, 初回治療でマクロライド系薬を投与さ れた患児 45 名を対象とした。

\section{2. 調査項目}

調査項目としては年齢, 性別, 併用薬の有無, ガイドライン準拠の有無, マクロライド耐性の有 無, 有熱期間 $\left(37.5^{\circ} \mathrm{C}\right.$ 以上の発熱〜解熱までの期 間), 罹病期間 $\left(37.5^{\circ} \mathrm{C}\right.$ 以上の発熱〜退院までの 期間)，入院〜解熱までの期間，血液検査值の 9 項目について電子カルテより後方視的に調査を 行った. なお, マクロライド耐性の有無について は感受性検査の実施症例を調査対象とした。

血液検査值はアスパラギン酸アミノ基転移酵素 (aspartate aminotransferase: AST)，アラニンアミ ノ基転移酵素（alanine aminotransferase: ALT）, 血 中尿素窒素 (blood urea nitrogen: BUN), 血清ク レアチニン (creatinine: $\mathrm{Cr}$ ), $\mathrm{C}$ 反応性蛋白 (C-reactive protein: CRP), 白血球数の 6 項目につ いて検討した。

\section{3. 調査内容}

\section{（1）使用薬剤による群分け}

マイコプラズマ肺炎の治療に対し azithromycin （AZM）が使用され，薬剤変更を行わずに治療を 完遂した症例を AZM 群とした. ペニシリン系薬 やセフェム系薬などを先行して使用した症例は除 外した. 前医で第 1 選択薬としてマクロライド系 薬を使用し，入院時にTFLXまたは MINOに薬 剂変更を行い, 治療した症例をそれぞれ TFLX 群 およびMINO 群とした。

\section{（2）第 2 選択薬間での治療期間の比較}

TFLX または MINOに薬剂変更後の治療期間を 比較検討するため, TFLX 群および MINO 群につ いて入院〜解熱までの期間を調査した。

\section{（3）治療期間に影響を与える要因の探索}

年歯令 (8 歳以上 $/$ 未満), 性別, 併用薬の有無, ガイドライン準拠の有無, マクロライド耐性の有 無の 5 要因について比較を行った。

ガイドラインではマクロライド系薬投与後 48 時間で解熱が得られない場合, マクロライド耐性 マイコプラズマを考慮して TFLX あるいは MINO への変更を推奨している. マクロライド系薬 (clarithromycin または AZM) 開始後 48 時間以内 に TFLXまたはMINO に変更した症例を準拠群, 48 時間を超えてから変更した症例を逸脱群とし 
た. 加えて, マクロライド系薬開始後 48 時間以 内に解熱が得られなかったが，そのまま継続され た症例もガイドライン逸脱群とした。 入院時に TFLX または MINO へ変更した症例では，入院時 に前医処方のマクロライド系薬開始後 48 時間を 経過しているかどうか確認した。

\section{4. 統計解析}

解析は StatView for Windows version 5.0（SAS Institute Inc, Cary, NC, USA）を用いて行った。 2 群間比較では Mann-Whitney's $U$ test, 3 群間比較 ではANOVAを用い，有意差がみられた場合，さ らに Scheffé 検定を行った。 $P$ 值 0.05 未満を統計 学的有意水準とした。本文中の数值は平均土標準 偏差で示した。

\section{5. 倫理的配慮}

本研究は, 当院臨床研究審査委員会で審査承認 （第 1550 号）を取得し, 個人情報保護に配慮して 行った.

\section{結果}

\section{1. 患者背景}

マイコプラズマ肺炎で当院に入院した患児 45 名の患者背景を表 1 に示した。使用薬剂によっ て群分けし, AZM 群が 9 例, TFLX 群が 19 例,
MINO 例が 17 例であった．年齢は MINO 群で 9.1 土3.2歳と高い傾向にあった. マクロライド耐性 株が検出された症例は, AZM 群（1/5例）に比 べ TFLX 群 (13/14 例) および MINO 群 (9/11 例) で有意に多かった，その他の性別, 併用薬の有無, ガイドライン準拠の有無, 血液検査值 (AST, $\mathrm{ALT}, \mathrm{BUN}, \mathrm{Cr}, \mathrm{CRP}$, 白血球数）に差は認めな かった.

\section{2. 第 2 選択薬間での治療期間の比較}

図 1 に示すように入院〜解熱までの期間は約 3 日であった. TFLX 群 $3.4 \pm 1.5$ 日に比べて MINO 群 $2.6 \pm 0.9$ 日と MINO 群において期間が短縮す る傾向にあった。 なお，有熱期間 - 罹病期間に特 に違いはみられなかった。

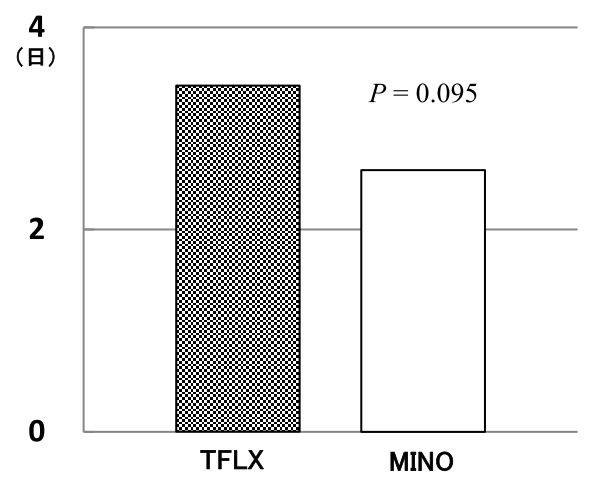

図 1 入院〜解熱までの期間の薬剤間比較

TFLX: tosufloxacin, MINO: minocycline. Mann-Whitney's $U$-test

表 1 患者背景

\begin{tabular}{|c|c|c|c|c|}
\hline & AZM $(n=9)$ & TFLX $(n=19)$ & MINO $(n=17)$ & $P$ \\
\hline 年齢 & $7.9 \pm 5.0$ & $7.3 \pm 2.4$ & $9.1 \pm 3.2$ & NS \\
\hline 8 歳以上 / 未満 & 5 & 11 & 12 & NS \\
\hline 性別（男 / 女） & 5 & 11 & 10 & NS \\
\hline 併用薬（あり／なし） & 7 & 17 & 10 & NS \\
\hline ガイドライン（準拠 / 逸脱) & 0 & 10 & 10 & NS \\
\hline マクロライド耐性（あり/なし） & 1 & 13 & 2 & $<0.05^{*}$ \\
\hline AST（U/L） & $29 \pm 9.5$ & $33 \pm 8.4$ & $29 \pm 7.5$ & NS \\
\hline ALT（U/L） & $14 \pm 6.6$ & $17 \pm 7.6$ & $14 \pm 7.5$ & NS \\
\hline BUN $(\mathrm{mg} / \mathrm{dL})$ & $9.8 \pm 2.5$ & $11 \pm 3.0$ & $9.7 \pm 1.8$ & NS \\
\hline $\mathrm{Cr}(\mathrm{mg} / \mathrm{dL})$ & $0.40 \pm 0.15$ & $0.39 \pm 0.13$ & $0.43 \pm 0.15$ & NS \\
\hline CRP $(\mathrm{mg} / \mathrm{dL})$ & $4.2 \pm 3.6$ & $2.1 \pm 1.7$ & $3.2 \pm 3.1$ & NS \\
\hline 白血球数 $(/ \mu \mathrm{L})$ & $7394 \pm 2294$ & $5995 \pm 1335$ & $8331 \pm 4414$ & NS \\
\hline
\end{tabular}

数值は平均土標準偏差で表記. ANOVA, Scheffé 検定. * AZM vs TFLX, AZM vs MINO. AZM: azithromycin, TFLX: tosufloxacin, MINO: minocycline, AST: aspartate aminotransferase, ALT: alanine aminotransferase, BUN: blood urea nitrogen, Cr: creatinine, CRP: C-reactive protein, NS: not significant. 


\section{3. 治療期間に影響を与える要因の探索}

次いで治療期間に影響を与える要因として年齢 (8 歳以上/未満), 性別, 併用薬の有無, ガイド ライン準拠の有無, マクロライド耐性の有無につ いて検討した。

年齢による差はみられなかった。併用薬ありの 症例では，感冒症状に対する対症療法薬が処方さ れていたが，抗菌薬以外の併用薬有無による差に ついて治療期間に違いはみられなかった。マクロ ライド耐性に関しては，マクロライド耐性群で有 熱期間 $9.3 \pm 1.9$ 日，罹病期間 $10.7 \pm 2.1$ 日，感 受性群で有熱期間 $8.9 \pm 3.4$ 日, 罹病期間 $10.0 \pm 3.3$ 日とマクロライド耐性群では, 治療期間が長くな る傾向にあったが，有意な差はみられなかった。 男児では有熱期間 $8.7 \pm 2.0$ 日, 罹病期間 $10.0 \pm 2.3$ 日であったが，女児では有熱期間 $9.7 \pm 1.9$ 日， 罹病期間 $11.1 \pm 2.2$ 日と治療期間が長くなり罹病 期間は有意に延長していた（表 2）.

ガイドライン準拠群で有熱期間 $7.9 \pm 1.7$ 日（逸 脱群 $10.0 \pm 2.2$ 日)であり有熱期間は有意に短く, 罹病期間 $9.4 \pm 1.6$ 日（逸脱群 $11.1 \pm 2.4$ 日）も 有意に短縮していた（図 2).

\section{考察}

ガイドラインではマイコプラズマ肺炎の治療に おいて，マクロライド系薬投与 48 時間後で解熱 が得られない場合，マクロライド耐性を考慮して TFLX あるいは MINOへの変更を推奨している. 今回検討した AZM 群ではいずれも48 時間を超え て投与が実施されたが，入院時に比して明らかな



有熱期間

罹病期間

図 2 小児呼吸感染症診療ガイドライン 2011 準拠の 有無による有熱期間と罹病期間の比較

网 ガイドライン準拠群, $\square$ ガイドライン逸脱群 MannWhitney's $U$-test. エラーバーは最大值と最小值, 箱内の線は中 央值を示している. ガイドライン準拠群 $(\mathrm{n}=16)$, ガイドラ イン逸脱群 $(\mathrm{n}=29)$. 有熱期間 $P=0.0027$, 罹病期間 $P=0.0077$.

臨床的改善が得られたため, 投与継続の判断がな されたと推察される. AZM 単独で治療を完遂し た症例ではマクロライド耐性の割合は $20 \%$ であっ たが，TFLX群では 93\%，MINO 群では $82 \%$ とマ クロライド耐性を有する症例が有意に多い結果が 得られた。一部の症例における解析ではあるが, マクロライド耐性の Mycoplasma pneumoniae に対 してもマクロライド系薬は有効であり, ${ }^{11)}$ ガイドラ インにも示されているように, マクロライド系薬 がマイコプラズマ肺炎治療の第 1 選択薬の位置づ けに変わりはない。これはマクロライド系薬特有 の抗炎症作用, サイトカイン産生抑制作用および 免疫賦活化作用 ${ }^{12}$ が影響していると考えられる.

MINO は作用機序的に静菌的な抗菌薬とされ, キノロン系薬など殺菌的な抗菌薬に比して抗菌作 用は劣ると思われる。一方で，今回の検討では

表 2 各要因における有熱期間と罹病期間

\begin{tabular}{ccccc} 
& 有熱期間 & $P$ & 罹病期間 & $P$ \\
\hline \hline 8 歳以上 $(\mathrm{n}=25)$ & $8.8 \pm 2.0$ & & $10.0 \pm 2.0$ & \multirow{2}{*}{0.08} \\
未満 $(\mathrm{n}=20)$ & $9.8 \pm 2.5$ & & $11.2 \pm 2.5$ & \\
男性 $(\mathrm{n}=23)$ & $8.7 \pm 2.0$ & & $10.0 \pm 2.3$ & \\
女性 $(\mathrm{n}=22)$ & $9.7 \pm 1.9$ & 0.13 & $11.1 \pm 2.2$ & $<0.05$ \\
併用薬あり $(\mathrm{n}=34)$ & $9.4 \pm 1.9$ & & $10.6 \pm 2.1$ & \\
なし $(\mathrm{n}=11)$ & $8.8 \pm 3.3$ & & $10.1 \pm 3.0$ & 0.49 \\
マクロライド耐性あり $(\mathrm{n}=23)$ & $9.3 \pm 1.9$ & & $10.7 \pm 2.1$ & \\
なし $(\mathrm{n}=7)$ & $8.9 \pm 3.4$ & & $10.0 \pm 3.3$ & 0.34 \\
\hline
\end{tabular}

数值は平均土標準偏差で表記. Mann-Whitney’s $U$-test. 
MINO 群において入院〜解熱までの期間が TFLX 群に比して短い傾向にあった．今回の知見を支持 する報告はほかにもあり，70\%の例で MINO 使用 後 24 時間以内に解熱と症状が改善しているとの 報告がある. ${ }^{13)}$ 一般的に，テトラサイクリン系薬 は一過性骨発育不全，エナメル質形成不全などの 有害事象を有し 8 歳未満には原則禁忌とされる. 結果として，小児全般に対する MINOの使用経 験は少ないと考えられ, Mycoplasma pneumoniae に対する MINOの感受性が良好に保たれていた 可能性が考えられる. 加えて MINO は, ツッガ ムシ病などリケッチア感染症に対し有効性が報告 されており， ${ }^{14)}$ その効果発現に際して抗菌作用以 外の免疫調整作用の存在が指摘されている. ${ }^{15,16)}$ MINO に関しても，マクロライド系薬同様の抗炎 症作用, サイトカイン産生抑制作用㧍よび免疫賦 活化作用の存在が，臨床症状の軽減に影響を及ぼ している可能性も考えられる.

TFLXを含むキノロン系薬の耐性化はDNA ジャイレースとトポイソメラーゼIV の酵素の遺伝 子の点突然変異で起こるため, 耐性化を容易にき たしやすいとされる、 ${ }^{17)}$ 一方, MINO を含むテト ラサイクリン系薬への耐性化にはプラスミド DNA が関与するが, Mycoplasma pneumoniae には プラスミドは存在しないためテトラサイクリン系 薬に対する耐性は生じにくいとの報告がある. ${ }^{10)}$ 小児ではこれまで有害事象の観点からキノロン系 薬の使用が少なく，現段階での Mycoplasma pneumoniae のキノロン感受性は良好である。し かしながら，キノロン系薬の小巟領域に扔ける多 用によって Mycoplasma pneumoniae のキノロン感 受性が低下した場合，成人領域における治療にも 影響が出る可能性が懸念される。このことからも キノロン系薬の漫然とした使用は避けるべきであ ろう。本研究では入院〜解熱までの期間が MINO 群において TFLX 群に比して短い傾向にあったこ とから, MINO の選択がより効果的である可能性 が考えられる.

マイコプラズマ肺炎は, 全ての年齢層で感染の リスクがあり，日本での罹患年齢は特に幼児期， 学童期，青年期が中心である。その発症には，性 差の違いも指摘されており, 発症数は一般感染症
の比率と異なり女児で多いと報告されているが, 地域によっては男児のほうが多く, 地域差も指摘 されている. ${ }^{18)}$ 加えて, 長期間の治療を有する症 例は女览に多かったとの報告がある. ${ }^{18)}$ 本研究に おいて, 男児と女児で症例数は変わらなかったが, 男児よりも女児で治療期間が長くなり, 性差に関 する報告と同様の結果が得られた。

ガイドラインではマクロライド系薬投与 48 時 間後の発熱の有無で，マクロライド感受性株と耐 性株の区別ができることから，48 時間経過後も 解熱が得られない場合に薬剤の変更を推奨してい る. 第 1 選択であるマクロライド系薬の無効例に 対して，速やかに他剤へ変更した場合に約 2 日間 の有熱期間・罹病期間の短縮がみられた。ガイド ラインに準拠すれば，患児の治療期間遷延を防ぐ と同時に, 治療期間短縮の可能性を示唆するため, 医療経済的にも有用な知見と思われる。マクロラ イド耐性マイコプラズマは増加傾向であるとはい え, 感受性の評価を全例に実施することは実質的 に困難である，今回の検討で得られた成績から， ガイドラインに基づく抗菌薬選択は有用な治療指 針と結論づけられる.

\section{利益相反}

開示すべき利益相反はない.

\section{引用文献}

1）国立感染症研究所感染症疫学センター, “注目 すべき感染症マイコプラズマ肺炎”, IDWR2012, 14, pp7-9.

2) Okazaki N, Narita M, Yamada S, Izumikawa $K$, Umetsu M, Kenri T, Sasaki Y, Arakawa Y, Sasaki T, Characteristics of macrolide-resistant Mycoplasma pneumoniae strains isolated from patients and induced with erythromycin, Microbiol Immunol, 2001, 45, 617-620.

3) Morozumi M, Takahashi $T$, Ubukata K, Macrolideresistant Mycoplasma pneumoniae: characteristics of isolates and clinical aspects of community-acquired pneumonia, JIC, 2010, 16, 78-86.

4) Akaike H, Miyashita N, Kubo M, Kawai Y, Tanaka T, 
Ogita S, Kawasaki K, Nakano T, Terada K, Ouchi K, Atypical Pathogen Study Group, In vitro activities of 11 antimicrobial agents against macrolide-resistant Mycoplasma pneumoniae isolates in pediatric patients: results from multicenter surveillance, Jpn JID, 2012, 65, 535-538.

5) Block S, Hedrick J, Hammerschlag MR, Cassell GH, Craft JC, Mycoplasma pneumoniae and Chlamydia pneumoniae in pediatric community-acquired pneumonia: comparative efficacy and safety of clarithromycin vs. erythromycin ethylsuccinate, Pediatr Infect Dis J, 1995, 14, 471-477.

6) Harris JA, Kolokathis A, Campbell M, Cassell GH, Hammerschlag MR, Safety and efficacy of azithromycin in the treatment of community-acquired pneumonia in children, Pediatr Infect Dis J, 1998, 17, 865-871.

7) Smith CB, Friedewald WT, Chanock RM, Shedding of Mycoplasma pneumoniae after tetracycline and erythromycin therapy, $N$ Engl J Med, 1967, 276, 1172-1175.

8） 小児呼吸器感染症診療ガイドライン作成委員会 (著), “小児呼吸器感染症診療ガイドライン 2011”, 株式会社協和企画, 東京, 2011, pp1-115.

9) American Academy of Pediatrics, 2012 Report of the committee on infectious diseases, 2012, 29th eds, p520, 801 .
10）河合泰宏, 尾内一信, 話題の耐性菌感染症の実際 マクロライド耐性マイコプラズマ感染症, 臨床 と微生物, 2013, 40, 253-258.

11）田中裕士, マイコプラズマ感染症〜現状と治療 の考え方〜, Mebio, 2013, 30, 7-12.

12）山岸由佳, 三鴨廣繁, マクロライド耐性マイコプ ラズマ, 薬局, 2012, 63, 2548-2552.

13）国立感染症研究所感染症疫学センター，“小児 におけるマクロライド高度耐性・肺炎マイコプ ラズマの大流行”, IASR, 2011, 32, 337-339.

14）志智大介, 谷澤朋美, 本田勝亮, 静岡県浜松市に おける過去7年間のつつが虫病, 低ナトリウム血 症に関する検討も含めて, 感染症学雑誌, 2008, 82, 335-340.

15) Pruzanski W, Greenwald RA, Street IP, Laliberte F, Stefanski E, Vadas P, Inhibition of enzymatic activity of phospholipases A2 by minocycline and doxycycline, Biochem Pharmacol, 1992, 44, 1165-1170.

16) Dunston CR, Griffiths HR, Lambert PA, Staddon $S$, Vernallis AB, Proteomic analysis of the anti-inflammatory action of minocycline, Proteomics, 2011, 11, $42-51$.

17）㛈峨知生, 話題の耐性菌キノロン耐性, 臨床と微 生物, 2013, 40, 219-223.

18）永山洋子, 小児期におけるRSV, 肺炎マイコプラ ズマ感染症の性差, 臨床免疫・アレルギー科, 2010, 54, 202-208. 